\title{
Social Representations of the Body and Bodily Care Practices of Older Adults
}

\author{
Anderson da Silveira ${ }^{1}$ \\ Brigido Vizen Camargo holds ${ }^{2}$ \\ Andreia Giacomozzi $i^{2}$ \\ ${ }^{1}$ Universidade do Sul de Santa Catarina, Palhoça, Santa Catarina, Brasil \\ ${ }^{2}$ Universidade Federal de Santa Catarina, Florianópolis, Santa Catarina, Brasil
}

\begin{abstract}
This study analyzed the relations between social representations of the body and the body care practices of older adults. Forty older adults, with ages varying from 60 to 84 years $(M=69 ; S D=7)$, matched by sex, took part in the study. The data were collected by means of in-depth thematic interviews, with the corpus analyzed using the IRaMuTeQ software. Differences between men and women were verified in representational contents and body practices. The male participants' social representations of the body were associated with biological functionality and health concerns, while the women emphasized the importance of physical appearance in their social relationships. Regarding body care practices, there was a higher incidence of food concerns in the men and the performance of physical activities in the women. Therefore, the results indicated that the body care practices vary according to the socials representations of the body and the sex of the participant.
\end{abstract}

Keywords: Social Representation; Social Psychology; Gerontology.

Representações Sociais do Corpo e Práticas de Cuidado Corporal de Pessoas Idosas

\begin{abstract}
Resumo
Esse estudo analisou as relações entre as representações sociais do corpo e as práticas de cuidado corporal de pessoas idosas. Participaram da pesquisa 40 idosos, com idades entre 60 e 84 anos $(M=69 ; D P=7)$, pareados por sexo. Os dados foram coletados por meio de entrevista bitemática em profundidade, cujo corpus foi analisado com auxílio do software IraMuTeQ. Verificou-se diferenças dos conteúdos representacionais e das práticas corporais entre homens e mulheres. As representações sociais do corpo do público masculino foram associadas à funcionalidade biológica e preocupação com a saúde, enquanto as mulheres ressaltaram a importância da aparência física nas relações sociais. Em relação às práticas de cuidado corporal, houve maior incidência de cuidados alimentares para o público masculino e de realização de atividades físicas para o público feminino. Assim, os resultados indicaram que as práticas de cuidado corporal variam segundo as representações sociais de corpo e conforme o sexo dos participantes.

Palavras-chave: Representação social; Psicologia social; Gerontologia.
\end{abstract}

Representaciones Sociales del Cuerpo y Prácticas de Cuidado Corporal para Personas Mayores

\begin{abstract}
Resumen
Este estudio analizó las relaciones entre las representaciones sociales del cuerpo y las prácticas de cuidado corporal de las personas mayores. En el estudio participaron cuarenta ancianos, con edades entre 60 y 84 años $(M=69$; $D S=7)$, emparejados por sexo. Los datos fueron recolectados por medio de entrevistas con doble temática realizadas en profundidad, cuyo corpus fue analizado a través del software IraMuTeQ. Se averiguaron diferencias en el contenido representativo y en las prácticas corporales entre hombres y mujeres. Las representaciones sociales del cuerpo de los participantes varones se asociaron con la funcionalidad biológica y los problemas de salud, mientras que las mujeres enfatizaron la importancia de la apariencia física en las relaciones sociales. Con respecto a las prácticas de cuidado corporal, hubo una mayor incidencia de preocupaciones alimentarias en los hombres, y la realización de actividad física en las mujeres. Por lo tanto, los resultados indicaron que las prácticas de cuidado corporal varían según las representaciones sociales del cuerpo y el sexo de los participantes.

Palabras clave: Representación social; Psicología social; Gerontología.
\end{abstract}

\section{Introduction}

The current demographic panorama shows an increase in the older adult population worldwide. Projections indicate that by $205021 \%$ of the world population will be over 60 years of age (Centro Internacional de Longividade Brasil, 2015). In Brazil it is estimated that the number of older adults will double in the coming years (Simões, 2016). The growth in the number of older adults is also accompanied by a longer life expectancy of the population (Instituto Brasileiro de Geografia e Estatística, 2019). This trend requires the establishment of new political devices to serve this population, such as Law 10.741/2003, in which 
the Brazilian government instituted the Statute for the Older Adult (Estatuto do Idoso), with the aim of ensuring the rights of older people.

The increase in the older adult population has led to sociocultural changes and the formation of new social representations about aging and advanced age (Jesuíno, 2012). Despite advanced age still being commonly approached as a uniform stage of life, characterized by negative stereotypes (Ayalon \& TeshRömer, 2018), the presence of the older adult in spaces previously little frequented by this population, such as gyms, universities and night parties, has contributed to the formation of new beliefs and attitudes towards older people. This means that, nowadays, advanced age gains new outlines and meanings.

The body is the physical apparatus about which subjectivity is constructed. With its expressions, movements and appearance, it is inscribed at the intersection of the individual and the collective (Jodelet, 1984/2017). Andrieu (2006) defined the human body as the result of individual and collective representations, constituting itself as a symbolic construction, crossed by culture and its symbols. Throughout history, the body has been perceived as an important element in maintaining the values and cultural identities of human groups. Sculpted from the values, models, attitudes and norms shared in the social environment, it is an important object of study for the Theory of Social Representations (Jodelet, 1982/2017).

In our society, the media has an important role in establishing norms and "beauty standards" (SánchezCabrero,León-Mejía, Arigita-García, \& Maganto-Mateo, 2019), imposing body models that value the young, thin and strong profile (Lachi \& Navarro, 2012). However, these appearances and bodily images reveal an ideal body that distances itself from the aged body (Blessmann, 2004). To reduce external pressures on older people, Hofmeier et al. (2017), proposed the inclusion of all types of bodies in the media, which could contribute to a better acceptance of aged bodies.

Based on lay theories, constructed in the social interaction between different individuals and groups, this study sought to understand the meanings attributed to the body by older adults, based on the Theory of Social Representations. Social representations are knowledge generated in everyday life, through communicational exchanges, which can be understood as a contemporary version of common sense (Moscovici, 2012). The study of the social representations of a group allows the identification of the modus operandi and the process of construction of this knowledge, in addition to its influence on the formation of assumptions, expectations and beliefs that shape the activities and situations in which individuals are inserted (Camargo, 2015).

Defining the extent to which social representations are related to social practices is a task that has mobilized the work of several theorists and researchers in Social Psychology (Abric, 2001; Campos, 2017). There is still no consensus on the relationship between representations and social practices (Almeida, Santos, \& Trindade, 2000). This relationship is considered "one of the major open questions in the study of the Theory of Social Representations" (Campos, 2017). Even so, it is understood that social representations have the function of being "guides for action" (Jodelet, 2001), "forming consensus on daily practices" (Vala, 2006) and, in this way, direct and justify the decisions taken in relation to the practices. For Camargo and Bousfield (2014), there is only a relationship between practice and social representation when the first is activated by the second. These authors argued that the social representation is an element, which together with sociodemographic, contextual and personal variables, can more concretely explain the adherence to a practice.

Despite the controversy surrounding the relationship between social representations and practices, some recent studies have shown the adoption of body care behaviors, based on socially shared representations (Aguiar, Camargo, \& Bousfield, 2018; Castro, Aguiar, Berri, \& Camargo, 2016; Castro, Giacomozzi, \& Camargo, 2018; Estrada-Mesa, Munoz-Echevarria, \& Cardona-Arias, 2016; Justo, Carmargo, \& Bousfield, 2018; Lavrilloux \& Masson, 2018; Silva et al., 2018). In the study by Aguiar, Camargo and Bousfield (2017), the relationship between social representations and body rejuvenation practices was identified. Based on the analysis of social attitudes, beliefs and norms, the result of the study indicated the existence of a correspondence between representations and rejuvenation practices. This result corroborates the idea that the body is an object collectively constructed from the sharing of "patterns" of thought and behaviors that "shape" individuals, stimulating them to achieve different body care practices. The relationship between representations and practices was also identified in the study by Silva et al. (2018). The authors observed that normative standards based on aesthetics or body health form representational fields that influence body weight 
control. These normative standards are propagated by the media, affecting the social representations of individuals and guiding their body care practices (Castro, Aguiar, Berri, \& Camargo, 2016)

Based on the above, this study sought to analyze the relationship between the social representations of the body and the bodily care practices adopted by older adult men and women. Considering the increase in the longevity of the Brazilian population, it is expected that this study can contribute to the development of interventions in the field of public policies associated with the health of older adults, with a focus on the bodily care of this population and the promotion of active aging (Kalache, 2016).

\section{Method}

\section{Participants}

This was a descriptive, empirical, qualitative study, with a cross-sectional and field research design. A total of 20 men and 20 women, residents of the Greater Florianópolis region, aged between 60 and 84 years, participated in this study $(M=69 ; S D=7)$. As an inclusion criterion, it was defined that the study participants had to be 60 years of age or older, as this is the age used in Brazilian legislation to classify the individual as an older adult.

Regarding education, 10 participants $(80 \%$ women) reported having completed elementary school, 16 (56\% men) completed high school and $14(64 \%$ men) reported having completed higher education. In relation to marital status, 21 participants were married ( $81 \%$ men), 8 divorced (62\% women), 9 female participants were widows and 2 were single. Concerning the socioeconomic level of the older adults, 18 participants indicated receiving an income above 5 minimum wages, 10 reported an income of 3 to 5 minimum wages, 9 from 1 to 3 minimum wages and 3 reported an income of up to 1 minimum wage. Regarding the involvement of the participants in groups that carry out activities for older adults, 17 women and 6 men said they participated constantly.

When asked about performing any type of physical activity, 29 participants reported regular practice. Walking was referred to as the most common physical activity among the participants, mentioned 15 times, followed by the gym (9), Pilates (6), gymnastics for older people (4), water aerobics (4), swimming (2) and adapted volleyball (2). The activities of adapted basketball, cycling, dancing and football were mentioned once each. Some of the participants indicated the practice of more than one type of activity.

Concerning their health conditions, 25 participants reported having a diagnosis of some type of chronic disease. The most cited pathologies were hypertension (19 cases) and type 2 diabetes mellitus (9 cases). When asked if they sought information about bodily care and health, 25 participants responded positively. In descending order, the older adults cited the following information channels: internet (14), television (9), doctors (6), magazines (4), books (3) and newspapers (1).

\section{Instruments}

Data collection was carried out through in-depth thematic interviews (Ghiglione \& Matalon, 1993). The interview script contained two verbal opening questions, which aimed to encourage the older adults to speak about the thoughts and meanings attributed to their own bodies and to identify the bodily care practices most adopted in their daily lives. The opening questions used were:

Question 1: Our body is very important and is part of every stage of our life. I would like to know what you think of your body, its importance, your feelings about it and your opinions.

Question 2: Now that we have spoken about what you think about your body, I would like you to describe to me all the care you take in relation to your body. What precautions do you know and which ones do you usually practice?

Aiming to collect the spontaneous content of the participants' speech, during the interviews, "classical techniques and particular techniques" were applied, as presented by Ghiglione and Matalon (1993).

The participants completed a sociodemographic questionnaire that contained questions about sex, age, marital status, education, income, health and physical activity. The questionnaire was applied at the end of the data collection, preventing the questions from interfering with the activation of the content of the responses evoked by the participants during the interview.

\section{Procedures}

Initially, the researchers made contact with three places that develop activities for older adults, located in the Greater Florianópolis region: two educational institutions and a meeting center maintained by the city council. With authorization from these institutions, contact was made with the older adults and, after explaining the study, they were invitation to participate. 
In these places, 23 interviews were conducted $(74 \%$ women). At the end of each interview, the participants were asked if they could indicate an older person from their social life that was available to participate in the study. From this, the other 17 participants ( $82 \%$ men) were accessed, who chose to participate in the interview in their homes. The average duration of the interview was 40 minutes.

All the interviews were recorded for later transcription and data analysis, with the participants' prior authorization, indicated through signing the consent form. The project was submitted to the Ethics Committee for Research with Human Subjects of (Information withheld by the Journal) and received approval through authorization No. 2.903.603.

\section{Data analysis}

The textual data generated from the contents of the interviews were analyzed with the aid of the software Interface de $\mathrm{R}$ pour les Analyses Multidimensionnelles de Textes et de Questionnaires (IRaMuTeQ). This computer program allows different types of statistical analysis on textual corpus. The Descending Hierarchical Classification Method (DHC) technique was used for the data analysis (Camargo \& Justo, 2013). This method identifies lexical classes formed from text segments (TSs) that share similar vocabularies, generated by co-occurring words, which constitute the specific vocabulary of each class. The entire class organization procedure is performed automatically by the software, avoiding the presence of bias on the part of the researcher during the codification of the textual corpus (Sbalchiero, 2018). The classes generated from the DHC are represented graphically in the form of a dendrogram, which displays the words associated with the TSs of the class based on a decreasing hierarchy organized from the chisquare scores, in which the minimum accepted value is 3.84 ( $p \leq .05$ for $d f=1)$.

\section{Results}

The corpus formed by the set of 40 interviews was submitted to a textual data analysis using the IRaMuTeQ software. The Descending Hierarchical Classification (DHC) divided the corpus into 40 texts, which were broken down into 1,708 text segments (TSs), of these $1,506(88.17 \%)$ were retained in the analysis (meaning indicators). A total of 202 TSs (11.83\%) were not incorporated into the DHC because they did not share enough semantic elements to be added to the classes.
On average, each text segment automatically generated by the software was made up of 35 words.

When the analysis was processed, the DHC separated the corpus into 3 sub-corpora, generating 4 classes (Figure 1). In the first stage, the corpus was separated into two sub-corpora ( $1^{\text {st }}$ partition), separating class 4 from the rest of the material. Then the larger sub-corpus was divided, giving rise to class $2\left(2^{\text {nd }}\right.$ partition or iteration). Finally, the third partition generated classes 1 and 3. The classification (DHC) was finalized, as the 4 classes were shown to be stable and composed of units of text segments with similar vocabulary.

The 4 classes generated by the DHC were named based on the content of the text segments (TSs). As can be seen in the dendrogram (Figure 2), the first 20 words of the typical text segments of each class were selected, all with a frequency greater than 9 and chisquare values in relation to classes of 3.84 or greater $(p$ $\leq .05$ for $d f=1$ ).

Class 4, called "eating practices", was formed by $175 \mathrm{TSs}$, which represents $11.62 \%$ of the content analyzed and was associated with the theme "bodily care" $\left(\chi^{2}=165.9 ; d f=1 ; p<.001\right)$ and older men $\left(\chi^{2}=\right.$ 9.5; $d f=1 ; p<.002)$. The elements related to this class express care regarding food in order to avoid diseases and maintain the proper functioning of the body. This care is reflected in the behavior of eating foods that are healthy, natural, whole and avoiding foods that may be harmful to the health. Foods such as red meat, sugars, fatty foods, carbohydrates, canned products and foods with pesticides, were referred to as sources of diseases and health hazards. The following report summarizes the contents of this class.

I try not to eat too much pasta, not to eat too much bread. I eat bread, whole grain bread. And I know the difficulties that people have, because they eat a lot of pasta, because of the carbohydrate. This harms the person's body. In the future the person may become diabetic. The person who eats a lot of fat may also have heart problems. You may have cholesterol. So, I take care of the food because of this. So that I don't have these problems in the future" (Participant 36, male, 60 years).

The report of taking care of the body through the act of eating emerged as a body care practice related to physical health. Mainly, revealing the intention to avoid the onset or worsening of chronic diseases such as diabetes and cholesterol, a concern that was present in the reports of other participants. 


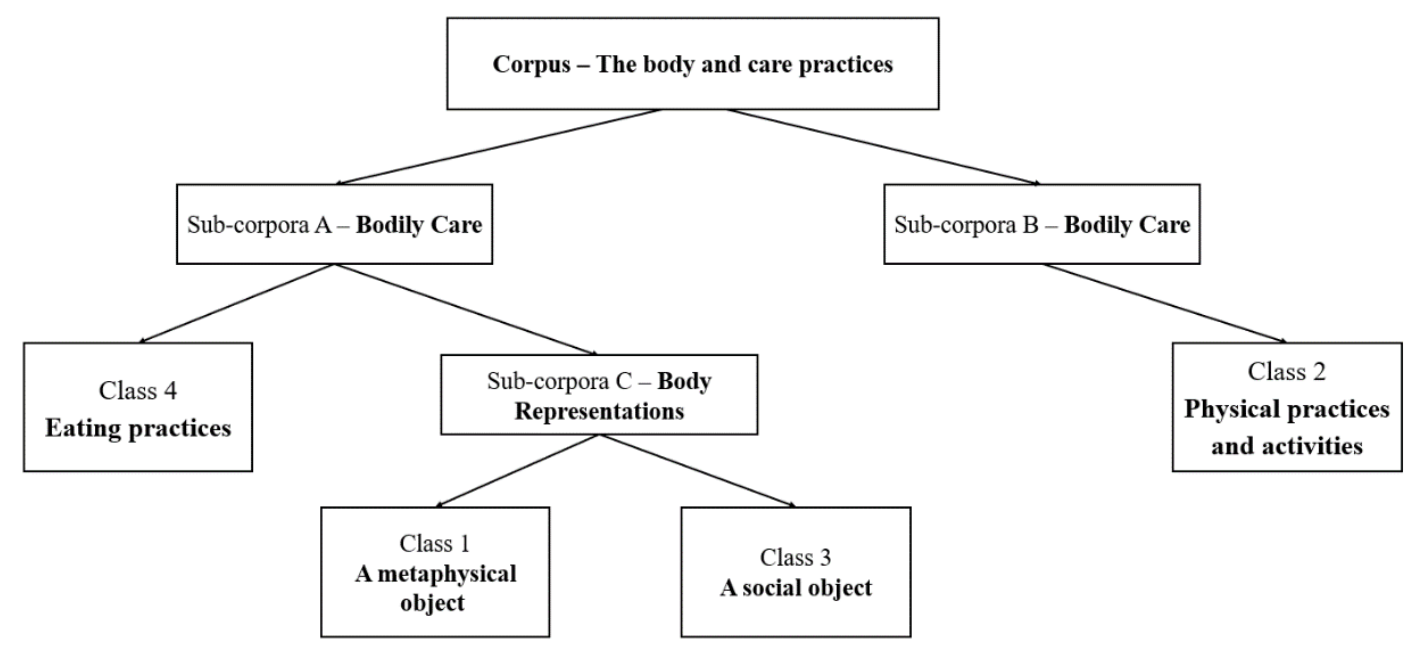

Figure 1. Classes generated by the Descending Hierarchical Classification - DHC.

Class 2, also associated with the theme "bodily care" $\left(\chi^{2}=90.1 ; d f=1 ; p<.001\right)$, received the name "physical activity practices". The term physical activity was adopted because it represents any type of body movement that results in caloric expenditure, being more comprehensive than physical exercise, for example. This class, composed of 399 TSs $(26.49 \%$ of the content analyzed), mainly represents statements by the women $\left(\chi^{2}=11.4 ; d f=1 ; p<.001\right)$. Physical activity was associated with health promotion and better quality of life as, according to some of the older women, it leads to more willingness to perform daily activities. In other statements, it was indicated to be a practice aimed at slimming the body. Walking was the physical activity most cited by all the participants in the study. In this class, this activity proved to be the central element in the organization of bodily care practices.

"The walk, sometimes I stop. Like I stopped last year,
because I broke my foot. I didn't walk. Now I have resumed,
because I feel the need. Also to lose weight a little, to keep
the body more in shape [...] And the walk is very good. You
start walking and feel a little tired, but then the next day you
feel ready. I walk in a flat area, which is quiet" (Participant
18, female, 65 years).

Class 2 text segments also highlighted the need perceived by the older adults to adapt the activities performed to their physical condition. The perception of physical wear is represented by the word "knee", mentioned in 15 text segments, associated with physical pain. However, even with some type of physical wear, the older adults stressed the importance of maintaining the habit of exercising physically, even though it is necessary to carry out low impact activities. This attitude is supported by the idea that physical activity helps to maintain the body and reduce pain resulting from physical wear.

As can be seen, classes 4 and 2 were related to the second theme of the interview (bodily care), which aimed to identify the types of bodily care adopted by the older adults. It can be seen that care practices related to food were predominantly associated with the male participants, while practices related to physical activities revealed a greater association with the female participants. Next, classes 1 and 3 will be described, which were associated by the DHC with theme 1 (body), which sought to identify the social representations of the body from the perspective of the older adults.

Class 1, named as "a metaphysical object", contains 488 TSs, contained $32.4 \%$ of the content analyzed by the DHC, with the highest retention of TSs in the corpus. It was associated with the theme "body" $\left(\chi^{2}\right.$ $=73.1 ; d f=1 ; p<.001)$. Participants associated with this class were predominantly male $\left(\chi^{2}=36.7 ; d f=1 ; p\right.$ $<0.001)$. The participants' statements indicate that the body is a divine gift, the house of God, the dwelling of a spirit, of the mind or even of the intellect itself. The need to accept and care for the body in some statements is attributed to the fact that the body is a concession made by God. 


\begin{tabular}{|c|c|c|c|c|c|c|c|c|c|c|c|}
\hline & & \multicolumn{4}{|c|}{$\begin{array}{l}\text { The body and care practices } \\
\qquad(1506 \mathrm{TSs}-88.17 \%)\end{array}$} & & & & & & \\
\hline \multicolumn{3}{|c|}{$\begin{array}{c}\text { Class } 4 \\
\text { Eating practices } \\
(175 \mathrm{TSs}-11.62 \%)\end{array}$} & \multicolumn{3}{|c|}{$\begin{array}{c}\text { Class } 2 \\
\text { Physical practices and } \\
\text { activities } \\
(399 \text { TSs }-26.49 \%)\end{array}$} & \multicolumn{3}{|c|}{$\begin{array}{c}\text { Class } 1 \\
\text { A metaphysical object } \\
(488 \text { TSs }-32.40 \%)\end{array}$} & \multicolumn{3}{|c|}{$\begin{array}{c}\text { Class } 3 \\
\text { A social object } \\
(444 \mathrm{TSs}-29.48 \%)\end{array}$} \\
\hline \multicolumn{3}{|c|}{$\begin{array}{c}\text { *Bodily Care } \\
\text { Men }\end{array}$} & \multicolumn{3}{|c|}{$\begin{array}{c}\text { "Bodily Care } \\
\text { Women }\end{array}$} & \multicolumn{3}{|c|}{$\begin{array}{l}\text { *Body } \\
\text { Men }\end{array}$} & \multicolumn{3}{|c|}{$\begin{array}{l}\text { *Body } \\
\text { Women }\end{array}$} \\
\hline Words & Freq. & $X^{2}$ & Words & Freq. & $X^{2}$ & Words & Freq & 1. $X^{2}$ & Words & Freq. & $X^{2}$ \\
\hline Comer & 69 & 405.95 & Caminhar & 43 & 90.03 & Corpo & 218 & 225.66 & Olhar & 46 & 72.04 \\
\hline Carne & 29 & 206.87 & Hora & 48 & 83.38 & Mente & 36 & 62.23 & Amigo & 29 & 52.12 \\
\hline Fruta & 28 & 183.3 & Academia & 36 & 77.8 & Pensar & & 53.36 & Aceitar & 29 & 49.1 \\
\hline Verdura & 21 & 161.98 & Caminho & 30 & 64.53 & Cuidar & 94 & 43.88 & Feio & 19 & 46.03 \\
\hline Gordura & 18 & 129.44 & Dia & 77 & 60.7 & Saúde & 46 & 43.83 & Dizer & 109 & 45.75 \\
\hline Arroz & 16 & 123.0 & Semana & 39 & 60.14 & Viver & 40 & 42.38 & Mulher & 22 & 45.36 \\
\hline Café & 19 & 114.61 & Caminhada & 29 & 57.45 & Deus & 46 & 40.38 & Espelho & 21 & 42.94 \\
\hline Comida & 20 & 109.86 & Exercício & 38 & 43.55 & Vida & 63 & 33.51 & Bonito & 19 & 41.85 \\
\hline Açúcar & 16 & 105.91 & Joelho & 15 & 42.04 & Achar & 114 & 32.98 & Mãe & 29 & 41.13 \\
\hline Pão & 13 & 99.74 & Pé & 19 & 37.77 & Físico & 34 & 31.63 & Velho & 33 & 38.71 \\
\hline Doce & 13 & 99.74 & Professor & 17 & 32.43 & Forma & 20 & 28.88 & Feliz & 16 & 34.55 \\
\hline Peixe & 13 & 99.74 & Ginástica & 14 & 30.91 & Doença & 23 & 27.38 & Arrumado & 14 & 33.8 \\
\hline Evitar & 24 & 93.65 & Braço & 11 & 30.74 & Manter & 36 & 26.99 & Pai & 23 & 32.78 \\
\hline Salada & 12 & 92.0 & Voltar & 24 & 30.56 & Humano & 14 & 25.68 & Mundo & 26 & 32.41 \\
\hline Tomar & 43 & 87.2 & Morar & 17 & 29.56 & Sentido & 21 & 23.63 & Amar & 19 & 28.96 \\
\hline Alimentação & 33 & 80.58 & Bicicleta & 12 & 29.17 & Graça & 20 & 21.8 & Família & 23 & 28.26 \\
\hline Almoço & 10 & 76.57 & Dormir & 22 & 27.96 & Gente & 121 & 21.63 & Saber & 82 & 27.38 \\
\hline Pão_integral & 9 & 68.86 & Mão & 14 & 27.55 & Estudar & 12 & 21.48 & Roupa & 19 & 26.46 \\
\hline Legume & 9 & 68.86 & Sozinho & 17 & 26.97 & Idade & 56 & 20.89 & Filho & 41 & 26.27 \\
\hline Integral & 9 & 68.86 & Perna & 24 & 26.91 & Procurar & 59 & 20.31 & Difícil & 21 & 24.17 \\
\hline
\end{tabular}

Figure 2. Dendrogram of the thematic corpus "the body and care practices".

"A very important phrase about this is, my body is how God made it, how it was conceived. It could not be better. And thankfully it is so, we have practically perfect limbs" (Participant 2, male, 68 years).

The notion of the body as an object that is beyond its physical dimension, covered with meanings anchored in immaterial religious/spiritual elements is corroborated by the importance that the participants represented by this class attach to the idea of mind. In a hierarchy of values, the mind is conceived as something that commands the body. This idea is reinforced by the belief that if the mind is well, the body will be well.

Parallel to the view of the body as a metaphysical object, some male participants also represented it using images very typical of their everyday universe. They compared the body to a car, a machine or a tool. These comparisons indicated the value given to the functional dimension of the body. When the body was anchored in the car, machine or instrument metaphor, its representation indicated more tangible and less immaterial 
realities, making reference to the body in its physical dimension.

"Well, what I think about the body. If you can use the word tool, it is a tool with which I can live, interact, perceive the world (Participant 35, male, 66 years)".

Composed of 444 TSs, $29.48 \%$ of the TSs in the corpus, class 3 , associated with the theme "body" $\left(\chi^{2}\right.$ $=89.5 ; d f=1 ; p<.001)$, received the name "a social object" and expresses the predominantly female representation of the body $\left(\chi^{2}=26.1 ; d f=1 ; p<.001\right)$. The words "look", "accept", "ugly", "beautiful”, "mirror", "neat", "clothes" reveal TSs in which the contents indicate a social representation based on predicates referring to the body as an object constituted by values and standards. These are the norms that define the adjectives of the body in our society: old, ugly, beautiful, thin, tall, among others.

The content of the participants' statements reveals the perception that their bodies are aging, and that in the mirror the signs of advanced age are already apparent. Skin that is no longer smooth, wrinkles, white hair and physical wear are markers that announce the time that has passed and will continue to have its effects on the body. At the same time, the older women reported that they accepted the aged body and stressed the importance of taking care of it in order to continue aging healthily.

So, I think that if I take care of the food and exercise, I can
stay as I am. I think it's important to continue aging health-
iby. So I don't complain. Okay, we notice, look in the mirror
and you see that you are no longer young. There is one more
wrink.le. However, I am calm on this point. I am very well
with my family. The husband never complained, so I think
the important thing is for me to be well psychologically and
accept the changes that we know will continue" (Participant
16, female, 71 years).

Care for clothes and appearance were contents that appeared recurrently in the statements of the women. The women, rather than the men, seem to be more concerned with being well dressed, and declared that society in general has more positive attitudes towards people with a better appearance.

\section{Discussion}

This study aimed to describe the relationship between the social representations of the body and the bodily care practices of older adults. Based on the lexicographic analysis, two social representations of the body were identified, one male and one female, reiterating what the literature has already documented about the influence of the gender variable in the elaboration of social representations (Torres, Camargo, Bousfield, \& Silva, 2015).

In the statements of some male participants, the social representation of the body was anchored in immaterial aspects, perceived as a divine gift, the dwelling of the spirit and the mind. In this sense, it denotes a notion of the body that moves away from its carnal and organic dimension and assumes the status of a "metaphysical object". This position may indicate the difficulty for men to talk about their own experiences and feelings related to the body. In a study conducted in France by Jodelet (1984/2017), it was observed that, in comparison to women, men referred to their bodies in a more abstract way. The impersonal approach to the body would be a way of taking refuge and concealing more direct bodily experiences, reserving them for the private level.

Body care practices, associated with the statements of the male participants, indicated a higher incidence of concern regarding biological functioning. Apparently, for these participants, care practices are anchored in behaviors that aim to prevent new diseases, ensuring the maintenance of their functional stability, from the physical point of view, with repercussions for mental health. Similarly, in the study by Ludgleydson, Sá and Amaral (2011), the authors observed that older men were more concerned with physiological functioning than with physical appearance. Similar results were found in the study by Coutinho, Tomazeti and Acosta (2013). The importance of physical functionality in the male universe was also evidenced in the study by Martins and Nascimento (2017), who investigated the social representations of the body after becoming ill with prostate cancer.

The social representations of the body, associated with older women, denote that the bodily experience of women is marked by the presence of social norms and values related to appearance (Hofmeier et al., 2017). The "mirror" and the "look" are elements that appeared only in the organization of the statements of the female participants. They indicate the concern of women to be satisfied with the body "for themselves" and for others. The women approached the body from their "bodily experience" and also from the "social interaction". They demonstrated that the interest in 
physical appearance remains, even with the passing of the years (Hofmeier et al., 2017).

In the women's statements, being in "neat clothes" appeared as an important element in order to be treated differently by others. Alferes (2006), when describing the determinants of interpersonal attraction, highlighted the importance of physical appearance. For the author, even if there is no consistent reason that makes sense, physically more beautiful people are easily associated with more positive personality traits. At the same time, being neat for the women was indicative of personal satisfaction: "I like do my makeup, I like to dress up, I like to feel beautiful" (Participant, 6, female, 64 years), which corroborates the idea that even in different socioeconomic realities, customs and aesthetic standards influence female body care (Fin, Portella, \& Scoregagna, 2017).

The word "accept", present in this class in 29 TSs, indicated that the participants accepted the body as it appears now. This may be an indication that the regulatory pressures on the body decrease as the years go by. The study carried out by Justo, Camargo and Alves (2014), exemplified this relationship, indicating that generational differences are more striking than the differences between the sexes for the organization of the social representation of the body of the study participants, since the younger ones gave more importance to aesthetics than the older ones.

The body and its aging are phenomena pervaded by physiological, social, cultural and psychic dimensions, among others (Caradec \& Vannienwenhove, 2015). The analysis of the data generated from the interviews allowed some salience in the statements present in the classes "body representations" and "bodily care practices" to be seen, with them being organized around the gender roles attributed to men and women. For the older adult men, care with food expressed a concern with the maintenance and functioning of physiological functions and the prevention/control of diseases such as diabetes and cholesterol. This care seems to be congruent with the social representations of the body for these study participants. This was especially the case for those older men whose representations were organized around elements related to the functionality and autonomy of the body and the concern with physical health.

In relation to the female participants, it was noticed that the social representation of the body was organized around the valorization of appearance and the body as an object situated in relation to the other, mediated by social values and norms. The women showed greater intimacy in the relationship with their own bodies and indicated that they are concerned with the way they are perceived by the "look" of others. The practice of physical activity was the body care practice most associated with the women. Like the men, the women were concerned with the health of the body, however, they also sought to perform physical activities because this practice provides them with a state of wellbeing and prevents physical wear.

Through this work it was possible to notice that the relationships between bodily care practices and social representations occur in a complex way. This includes assuming the polysemy existing around bodily care practices (Caradec \& Vannienwenhove, 2015), since physical activity can signify aesthetic care, physical health or even be a source of psychological well-being. The results achieved indicated that bodily care practices vary according to the social representations of the body and according to the sex of the participants. Therefore, the gender variable remains an important variable in studies on the social representations of the body. It is possible to identify that the social constructions of femininity and masculinity structure the way of experiencing the body and bodily self-care (Santos, 2008). In this study, the statements of the participants showed that the older women were more concerned with appearance and aesthetics and the older men with the functionality of their bodies.

This study did not intend to exhaust the reflections on the theme, although it certainly advances the comprehension of the intersections between bodily care practices and social representations of the body among older adults, relevant to the area of gerontology and for guiding the actions carried out by healthcare providers that serve the older adult population. Among its contributions, the comparison between the representations and the body care practices of older men and women stands out, since the studies on the social representations of older adults about the body generally focus on issues related to the physical changes resulting from aging (Coutinho, Tomazeti, \& Acosta, 2013) or the relationship between body and advanced age (Ludgleydson, Sá, \& Amaral, 2011). However, no Brazilian studies were found that have investigated the direct relationship between the body representations and care practices of older people.

Some limitations were identified and can be indicated as suggestions for future studies. Despite finding some relationships between the practices and the social representations of the male and female 
participants, the study could further deepen the understanding of this relationship, through the control of other variables. Accordingly, it is suggested that future studies seek to identify the effects of sources of information on the development of representations about the body and bodily care practices. In the context of older adults, information acquired through the media and religion stands out. Studies should be carried with the control of social groups of greater contrast (older adults from different professional backgrounds, from specific groups, from different social classes and practitioners of different religions, etc.), in order to identify possible differences in relation to representations and practices in relation to the groups to which they belong.

Further studies should also be performed based on the comparison between male and female, physically active and non-active older adults. These intergroup comparisons may further elucidate the relationship between social representations and care practices. Greater control over the age groups of the older adults is also recommended, as age differences can interfere with the content of the social representations and care practices.

\section{References}

Abric, J. C. (Ed.). (2001). Prácticas sociales y representaciones. México, DF: Ediciones Coyocán.

Aguiar, A., Camargo, B. V., \& Bousfield, A. B. S. (2017). Representações sociais e práticas corporais de rejuvenescimento para mulheres de meia-idade. Psicologia e Saber Social, 6(1), 47-66. doi: https:/ / doi. org/10.12957/psi.saber.soc.2017.30665

Aguiar, A., Camargo, B. V., \& Bousfield, A. B. S. (2018). Envelhecimento e Prática de Rejuvenescimento: Estudo de Representações Sociais. Psicologia: Ciência e Profissão, 38(3), 494-506. doi: https:// dx.doi.org/10.1590/1982-37030004492017

Alferes, V. R. (2006). Atração Interpessoal, Sexualidade e Relações Intimas. Em J. Vala \& M. B. Monteiro (Eds.), Psicologia Social (pp. 125-158). Lisboa: Fundação Calouste Gulbenkian.

Almeida, A. M. O., Santos, M. F. S., \& Trindade, Z. A. (2000). Representações e práticas sociais: contribuições teóricas e dificuldades metodológicas. Temas em Psicologia, 8(3), 257-267. Available at: http://pepsic.bvsalud.org/scielo. php?script $=$ sci_arttext\&pid $=$ S1413-389X2000000 $300005 \& \operatorname{lng}=\mathrm{pt} \& \operatorname{lng}=\mathrm{pt}$

Andrieu, B. (2006). Le dictionnaire du corps em sciences bumaines e sociales. Paris: CNRS.

Ayalon, L., \& Tesch-Römer, C. (2018). Introduction to the Section: Ageism - Concept and Origins. Em L. Ayalon \& C. Tesch-Römer (Eds.), Contemporary Perspectives on Ageism (pp. 1-10). Cham: Springer.

Blessmann, E. J. (2004). Corporeidade e envelhecimento: o significado do corpo na velhice. Estudos Interdisciplinares do Envelhecimento, 6, 21-3. Available at: https://seer.ufrgs.br/RevEnvelhecer/article/ download/4737/2661

Instituto Brasileiro de Geografia e Estatística - IBGE (2019). Tábua completa de mortalidade para o Brasil - 2018: breve análise da evolução da mortalidade no Brasil. Disponível em https://biblioteca.ibge. gov.br/visualizacao/periodicos/3097/tcmb_2018. pdf

Camargo, B. V. (2015). Serge Moscovici (14/06/1925 - 16/11/2014): um percussor inovador na Psicologia Social. Memorandum, 28, 240- 245. Available at: http://www.fafich.ufmg.br/memorandum/wpcontent/uploads/2015/05/camargo01.pdf

Camargo, B. V. \& Bousfield, A. B. S. (2014). Em direção de um modelo explicativo da relação entre representações sociais e práticas relativas à saúde: a ideia de adesão representacional. Em E. M. Q. O. Chamon, P. A. Guareschi \& P. H. F. Campos (Eds.), Textos e debates em representação social (pp. 261 284). Porto Alegre: ABRAPSO.

Camargo, B. V., \& Justo, A. M. (2013). IRAMUTEQ: Um software gratuito para análise de dados textuais. Temas em Psicologia, 21(2), 513-518. doi: http://dx.doi.org/10.9788/TP2013.2-16

Campos, P. H. F. (2017). Editorial da seção - O estudo das relações entre práticas sociais e representações: retomando questões. Psicologia e Saber Social, 6(1), 42-46. doi:10.12957/psi.saber.soc.2017.30664

Caradec, V., Vannienwenhove, T. (2015). L’expérience corporelle du vieillissement. Gérontologie et Société, Caisse nationale d'assurance vieillesse 2015, Regards croisés sur le corps vieillissant, 37 (148), pp.83-94. doi: https://dx.doi.org/10.3917/gs.048.0083

Castro, A., Aguiar, A., Berri, B., \& Camargo, B. V. (2016). Representações sociais do rejuvenescimento na 
mídia impressa. Temas em Psicologia, 24(1), 117-130. doi: https://dx.doi.org/10.9788/TP2016.1-08

Castro, A., Giacomozzi, A. I., \& Camargo, B. V. (2018). Representações sociais, zona muda e práticas sociais femininas sobre envelhecimento e rejuvenescimento. Estudos Interdisciplinares em Psicologia, 9(2), 58-77. doi: http:// dx.doi.org/10.5433/2236-6407.2018v9n2p58

Centro Internacional de Longevidade Brasil. (2015). Envelhecimento ativo: um marco politico em resposta à revolução da longevidade. Available at: http://ilcbrazil.org/portugues/w pcontent/uploads / sites/4/2015/12/Envelhecimento-Ativo-UmMarco-Pol\%C3\%ADtico-ILC-Brasil_web.pdf

Coutinho, R. X., Tomazeti, R.V., \& Acosta, M. A. F. (2013). Representação de corpo na velhice: o corpo real versus o corpo social. Revista Kairós Gerontologia,16(4), pp.215-236. doi: https://doi. org/10.23925/2176-901X.2013v16i4p215-236

Estrada-Mesa, Diego Alejandro, Muñoz-Echavarría, Andrea Estephany, \& Cardona-Arias, Jaiberth Antonio. (2016). Representaciones sociales sobre el cuerpo en estudiantes de Medicina, Medellín, 2014. Iatreia, 29(1), 39-50. https://dx.doi.org/10.17533/ udea.iatreia.v29n1a04

Fin, T. C., Portella, M. R., \& Scortegagna, S. A. (2017). Velhice e beleza corporal das idosas: conversa entre mulheres. Revista Brasileira de Geriatria e Gerontologia, 20(1), 74-84. https://doi. org/10.1590/1981-22562017020.150096

Ghiglione, R.; Matalon, B. (1993). O inquérito: teoria e prática. Oeiras: Celta Editora.

Hofmeier, S. M., Runfola, C. D., Sala, M., Gagne, D. A., Brownley, K. A., \& Bulik, C. M. (2017). Body image, aging, and identity in women over 50: The Gender and Body Image (GABI) study. Journal of women \& aging, 29(1), 3-14. doi: 10.1080/08952841.2015.1065140

Jesuíno, J. C. (2012). Imagens da velhice. Em L. F. R. Tura \& A. O. Silva (Eds.), Envelhecimento e representações sociais (pp. 51-68). Rio de Janeiro: Quartet/ Faperj.

Jodelet, D. (1982/2017). Representações, experiências, práticas corporais e modelos culturais. Em D. Jodelet (Ed.), Representaçoes sociais e mundos de vida. (pp. 272-292). São Paulo: Fundação Carlos Chagas; Curitiba: PUCPress.

Jodelet, D. (1984/2017). A representação do corpo e suas transformações. Em D. Jodelet (Ed.), Representações sociais e mundos de vida. (pp. 272-292). São Paulo: Fundação Carlos Chagas; Curitiba: PUCPress.

Jodelet, D. (2001) Representações sociais: um domínio em expansão. In: D Jodelet (Ed.), As Representações Sociais (pp. 17-44). Rio de Janeiro. RJ: Editora UERJ.

Justo, A. M., Camargo, B. V, \& Alves, C. D. B. (2014). Os efeitos de contexto nas representações sociais sobre o corpo. Psicologia: Teoria e Pesquisa, 30(3), 287-297. doi: https://dx.doi.org/10.1590/ S0102-37722014000300006

Justo, A. M., Camargo, B. V., \& Bousfield, A. B. S. (2018). Sobrepeso e controle de peso: pensamento leigo e suas dimensões normativas. Revista Psicologia-Teoria e Prática, 20(2). doi: http:/ / dx.doi.org/10.5935/1980-6906/psicologia. v20n2p213-224

Kalache, A. 2016. Active ageing and age-friendly cities - A personal account. Em. T Moulaert, \& S Garon (Eds.), Age-friendly cities and communities in international comparison. Cham: Springer International.

Lachi, P., \& Navarro, P. (2012). O corpo moldado: corporeidade mediada e subjetiva. Em I. Tasso, \& P. Navarro (Eds.), Produção de identidades e processos de subjetivação em práticas discursivas. Maringá: Eduem/ SciELO Books.

Lavrilloux, M., \& Masson, E. (2018). Le régime: une affaire de femme et non d'homme? Influence des représentations sociales sur la description et la nomination des pratiques de contrôle alimentaire. Les Cahiers Internationaux de Psychologie Sociale, (1), 71-95. doi: https://doi.org/10.3917/cips.117.0071

Ludgleydson, A., Sá, Elba C. N., \& Amaral, E. B. (2011). Corpo e velhice: um estudo das representações sociais entre homens idosos. Psicologia: Ciência e Profissão, 31(3), 468-481. doi: https:// dx.doi.org/10.1590/S1414-98932011000300004

Martins, A. M., \& Nascimento, A. R. A. do. (2017). Representações sociais de corpo após o adoecimento por câncer na próstata. Psicologia Em Estudo, 22(3), 371-381. doi: https://doi.org/10.4025/psicolestud.v22i3.31728 
Moscovici, S. (1961/2012a). A psicanálise, sua imagem e seu público. Petrópolis: Vozes.

Sánchez-Cabrero, R., León-Mejía, A. C., Arigita-García, A., \& Maganto-Mateo, C. (2019). Improvement of Body Satisfaction in Older People: An Experimental Study. Frontiers in Psychology, 10: 2823. doi: 10.3389/fpsyg.2019.02823

Santos, L. A. D. (2008). Reflexões sobre a tríade corpo, comer e comida. Em Santos, Ligia Amparo da Silva (Ed.), O corpo, o comer e a comida: um estudo sobre as práticas corporais e alimentares no mundo contemporâneo (pp. 21-48). Salvador: EDUFBA.

Sbalchiero S. (2018) Topic Detection: A Statistical Model and a Quali-Quantitative Method. Em Tuzzi A. (Eds), Tracing the Life Cycle of Ideas in the Humanities and Social Sciences. Quantitative Methods in the Humanities and Social Sciences. Springer, Cham.

Silva, D., Santos, M., Justo, A. M. Bousfield, A. B. S., \& Camargo, B. V. (2018). Representações Sociais Relativas ao Controle de Peso Corporal para Pessoas com Sobrepeso. PSI UNISC, 2(2), 66-77. doi: https://doi.org/10.17058/psiunisc.v2i2.11703

Simões, C. C. S. (2016). Relações entre as alterações históricas na dinâmica demográfica brasileira e os impactos decorrentes do processo de envelhecimento da população. Rio de Janeiro: IBGE, Coordenação de População e Indicadores Sociais.

Torres, T. L.; Camargo, B. V.; Boulsfield, A. B.; \& Silva, A. O. (2015). Representações sociais e crenças normativas sobre envelhecimento. Ciência \& Saúde Coletiva, 20(12), 3621-3630. doi: http://dx.doi. org/10.1590/1413-812320152012.01042015.

Vala, J. (2006). Representações sociais e psicologia social do conhecimento quotidiano. Em J. Vala, \& M. B. Monteiro (Eds.), Psicologia Social (pp. 457-502). Lisboa, Portugal: Fundação Calouste Gulbenkian.

Recebido em: 27/06/2019

Reformulado em: 27/05/2020

Aprovado em: 13/07/2020 
About the authors:

Anderson da Silveira has a BSc in Psychology from the Universidade do Sul de Santa Catarina and an MSc in Psychology from the Universidade Federal de Santa Catarina (UFSC). He is currently a collaborator at the Laboratório de Psicologia Social da Comunicação e Cognição (LACCOS-UFSC) and Professor of the Psychology Course at the Universidade do Sul de Santa Catarina.

ORCID: https://orcid.org/0000-0002-6231-2574

E-mail: andersonsilveirapessoal@gmail.com

Brigido Vizeu Camargo holds a PhD in Social Psychology (École des Hautes Études em Sciences Sociales). He is a full professor of the Department of Psychology of the Universidade Federal de Santa Catarina (UFSC), and permanent professor in the PPGP-UFSC. He is the founder of the Laboratório de Psicologia Social da Comunicação e Cognição (LACCOS-UFSC).

ORCID: https://orcid.org/0000-0002-9529-4923

E-mail: brigido.camargo@yahoo.com.br

Andreia Giacomozzi is a Psychologist from UFSC, with an MSc and PhD in Psychology from the Postgraduate Program in Psychology at UFSC and is a Post-doctoral researcher in Psychology at the Università degli Studi di Padova (Italy). She is a researcher of the Laboratório de Psicologia Social da Comunicação e Cognição (LACCOS-UFSC) and a professor of the PPGP-UFSC and the Psychology Department of UFSC.

ORCID: https://orcid.org/0000-0002-3172-5800

E-mail: agiacomozzi@hotmail.com

Contact:

Anderson da Silveira

Laboratório de Psicologia Social da Comunicação e Cognição Universidade Federal de Santa Catarina - Centro de Filosofia e Ciências Humanas - Departamento de Psicologia - Bloco E - 5 andar Campus Universitário Trindade Florianópolis-SC, Brazil

CEP: 88040-900 